\title{
THE INCREASE OF ENTERPRISES' INNOVATIVE DEVELOPMENT BASED ON THE NETWORK APPROACH
}

\author{
Olena Gudz ${ }^{1}$ \\ State University of Telecommunications, Ukraine \\ Nataliya Prokopenko² \\ PHEE "European University", Ukraine
}

\begin{abstract}
The purpose of the paper is studying the role and problems of the innovative development of domestic enterprises, discovering the factors that influence these processes. Methodology. The methodology for the study was based on logical and historical methods, methods of the system-functional approach, methods of scientific abstraction, systematization, grouping, generalization and formalization, analysis and synthesis, economic and statistical methods, and method of questioning and peer review. Results. It is studied the essence and substantiated the expediency of the network approach use, it is outlined its capabilities and limitations, determined the effectiveness of network innovation structures, and developed the proposals for activating the innovative development of enterprises in new dimensions of the economic space based on the network approach. Practical implications. The proposed measures will promote the activation of innovative development for domestic enterprises, improve the quality of business chains, competitiveness and management structures, and provide the development of new market segments. Value/originality. The information background for the paper was the official data of the State Statistics Service of Ukraine, statistical and financial statements of enterprises, rating estimates by the international agency Bloomberg Rankings, analytical report "Global Innovation Index" (World Intellectual Property Organization, WIPO), the report of the European Innovation Scoreboard, scientific publications of domestic and foreign researchers, normative reference literature, analytical and logical generalizations and observations of authors, Internet information resources.
\end{abstract}

Key words: innovations, innovative development, enterprises, network approach, network innovative structures.

JEL Classification: R14, D18, P2

\section{Introduction}

In the world, there is a formation of a new type of entrepreneurship, the basis of which are knowledge and information and communication technologies, and which is focused on the activation of innovative development. That is, the speed of building social needs, the intensification of scientific and technological progress, the aggravation of competition and other factors require domestic enterprises to activate the innovative development using new non-traditional approaches. Therefore, the activation of innovative development for domestic enterprises based on a network approach, the emergence of which is conditioned by the progress of information and communication technologies and the deployment of business democratization processes, will promote the generation of additional competitive advantages, provide economic benefits, assimilate new market segments, and increase labour productivity. This approach solves a wide range of problems that require qualitative changes in the activities of enterprises since it is "in the network structures and the network principle of the organization of economic activity, a new driver of innovation development of enterprises" is seen (Sichkarenko, 2015). Based on this, the chosen topic of research is particularly relevant; inhibition of innovative development of domestic enterprises is due to their backwardness, loss of competitiveness, and economic crisis.

The issue of enterprises' transition to an innovative way of development, measures to enhance their innovative activity in scientific publications are covered fairly widely. When considering this problem, researchers most often rely on the development of: J. Schumpeter, C. Oppenlander, P. Drucker, A. Anchishkin, N. Kondratyev, D. Kokurin, J. Yakovets,

\footnotetext{
Corresponding author:

${ }^{1}$ Department of Management, State University of Telecommunications.

E-mail: gudzee@ukr.net

${ }^{2}$ Department of Finance, Accounting and Taxation, PHEE "European University".

E-mail: nprokopenko@gmail.com
} 
S. Ilyashenko, P. Pererva, L. Fedulova, A. Yastremskaya and others. However, issues of mainstreaming innovative development for enterprises based on the network approach remain the object of lively scientific discussions, which means space for the further development of scientific research.

The aim of the article is to highlight the role and problems of innovative development for domestic enterprises, to find out factors affecting these processes, discover the essence and the rationale for the use of a network approach, define its capabilities and limitations, define the effectiveness of network innovation structures, and to develop proposals to enhance the innovative development of enterprises in new dimensions of the economic space based on the network approach.

\section{Challenges and condition of the innovative development of Ukrainian enterprises}

The need to intensify the innovative development of domestic enterprises is generated, mainly, with the emergence of new challenges and deformations in the economic space. To such challenges and deformations today can be attributed: political instability and conduct of the anti-terrorist operation in the east of the country, saturation of the market and a rapid decline in consumer demand of the population; development of radical qualitative innovations, especially for production technologies; deployment of inflationary processes; expansion of the market assortment; destruction of the banking system, and as a result of the narrowing of business lending; threats of competitors. In contrast to existing challenges and deformations, there is a slowdown in the innovative development of enterprises. So, during the 2014-2016 years, the share of enterprises engaged in innovative activities was $18.4 \%$, incl. technological innovation $-11.8 \%$ ( $5.7 \%$ for the product and $10.3 \%$ for the process), non-technological $13.4 \%$ (8.7\% - organizational and $10.2 \%$ - marketing) (Popov, 1994). It should be noted that there is a close interdependence between the size of the enterprise and its innovative activity, since additional resources, in particular, a certain number of employees for research and development, are needed to develop innovations. The largest share among technological and nontechnological innovation enterprises was observed in large enterprises (31.4\% and 28.1\%).

By industry, in 2014-2016, the largest share of innovation had information and telecommunications enterprises $(22.1 \%)$, processing industry enterprises $(21.9 \%)$, enterprises of financial and insurance activities (21.7\%), and enterprises of activities in the field of architecture and engineering (20.1\%) (Popov, 1994). According to the territorial location, a high level of innovative activity was noted at the enterprises of the Rivne, Kharkiv regions, and in Kyiv.
In 2016, enterprises allocated 23.2 billion UAH for innovative needs, including the purchase of machinery, equipment, and software in the amount of 19.8 billion UAH. Almost a third part of enterprises carried out innovative activities to introduce new or substantially improved products or processes. Innovations were mainly carried out at the expense of the enterprises' own funds $(89.5 \%)$, foreign investors' funds $(3.1 \%)$, and other sources $(2.9 \%)$ (State Statistics Service of Ukraine, 2017). The main partners for enterprises on innovative cooperation were primarily suppliers of equipment, materials, software, and customers (13.7\%). The share of enterprises cooperating with scientific institutions was $8.4 \%$.

At the same time, we note that the innovative potential of countries is determined by indicators of the availability and growth of the number of doctors and candidates of sciences and an increase in the relative number of persons with higher education (according to which Ukraine is among the top ten economically powerful countries). The share of doctors and candidates of science among performers of scientific research was 27.9\%, among researchers $-42.6 \%$ (State Statistics Service of Ukraine, 2017). In 2016, the proportion of performers of scientific research in the total number of employed population was $0.60 \%$, including researchers $-0.39 \%$. According to Eurostat, in 2014, this share was high in Denmark (3.07\% and $2.09 \%)$, Finland $(2.95 \%$ and $2.12 \%)$, Norway (2.73\% and 1.90\%) (World Intellectual Property Organization, 2017).

\section{Comparison of indicators of Ukrainian enterprises' innovative development with enterprises from other countries}

The world does not stop its development in order to give domestic enterprises an opportunity to catch up. The maximum innovation that J. Schumpeter defined as "creative destruction" helps to avoid various business problems, and Ukraine's enterprises are characterized by innovative backwardness compared to other countries. For example, according to the European Innovation Scoreboard in 2016, Ukraine was in the last on the level of innovation - the fourth group - "modest innovators" with an index of 0.1889 (maximum 1). Compared with other EU countries, the backlog of Ukraine is more than 4 times from the first group of "Innovation Leaders" (the first place in the rating takes Sweden 0.796). In general, for Ukraine, the largest value of this index was observed in $2013-0.1893$ (European Commission, 2017).

The low innovation activity of Ukrainian enterprises is confirmed by the rating of the international agency Bloomberg Rankings. So, in 2017, Ukraine took the 46th place in the top 50 innovations and economies of the world (Innovation Index) (in 2015 - 33, 2016 - 41) (Bloomberg, 2017). 
Based on the analytical report "Global Innovation Index" (World Intellectual Property Organization, WIPO), according to the country's innovation rating in relation to GDP, Ukraine was classified as lower-middleincome and ranked 64th out of 141 countries (World Intellectual Property Organization, 2017). The share of research and development expenditures in Ukraine's GDP was $0.48 \%$, including $0.16 \%$ at the expense of the state budget. In 2015, the same figure in the EU countries averaged $2.03 \%$. The highest rates were shown by Sweden - 3.26\%, Austria - 3.07\%, Denmark $3.03 \%$, Finland $-2.90 \%$, Germany $-2.87 \%$ (European Commission, 2017).

That is, it can be argued that domestic enterprises have not yet become on the rails of activating innovative development. The most vulnerable for Ukraine are: "Political stability and security" (125th place), "Easiness of resolving issues of bankruptcy" (113th place), "Political environment" (123rd place), "GDP per unit of energy" (115th place). High rankings in the world competitiveness ratings of national economies are held only by those countries whose outstanding achievements are due to attracting the innovation factor: Finland, Great Britain, Netherlands, Singapore, Japan, USA, South Korea, Ireland (Ivchenko, 2007). Innovations have the ability to rapidly change entire sectors of the economy and bring tremendous economic, social, and financial benefits to countries that create a supportive environment for them (European Commission, 2017). That is, for more effective implementation of their capabilities, enterprises must move from single mastering of innovations to a large-scale integrated process of generation and implementation of innovations, namely, to intensify their innovative development.

\section{Braking the factors of enterprises' innovative development}

Managers of enterprises call holding factors that prevented them from mastering innovations in 20142016, namely: low demand for innovation (60.7\%), lack of funds (57.1\%), lack of ideas or opportunities for innovations (54.7\%), high costs for innovation (52.3\%), negative experienceininnovation development (51.2\%), difficulties in attracting state support for innovations (38.5\%), unfavourable regulatory framework (34.1\%), low competitiveness of the enterprise (34.7\%), high competition (31.2\%), lack of loans (29.4\%), uncertain demand for innovative products $(16.4 \%)$, absence of skilled labourers $(11.76 \%)$, absence of reliable partners (8.2\%).

It should be added to this list that business-units are becoming more and more pluralistic; democratic; interconnections between different business contractors are complicated; it is significantly increasing the uncertainty, threats and risks; globalization is unfolding, the influence of external factors on the state's internal politics is growing; competitive struggle is intensifying; society IT development is intensifying; the confidence of entrepreneurs and the population towards state authorities is falling down. The above requires the revision of traditional approaches to activating the innovative development for enterprises, as they do not meet the challenges of the present, and in the conditions of the information and communication revolution do not provide the expected activation and efficiency of innovative processes.

\section{The feasibility and essence substantiation for the network approach}

Now, activation of innovation activity involves an increase in the degree of openness and interaction with partners. Multiplicity, versatility, and complexity of such an interaction prove the expediency and effectiveness of the application of the network approach.

In fact, a network approach is an answer to the challenges, the changing conditions of enterprises and their expectations in the uncertain and full of threats and information in the economic space. A network approach defines a system of relationships between enterprises without the domination of one of them. In essence, it provides for the use of one of the types of horizontal integration, contributes to the maximum attraction of available resources for the provision of innovative products and services, the development of technological innovations, the development of competencies, competitive advantages, innovation, production, information, and intellectual potential in the contour of a single multi-polar information and communication space. Among the significant advantages of the network approach, there should be high organizational capacity, more efficient use of resources, increased competitiveness, expansion of the horizons of opportunities to solve complex innovation problems and improve the quality of services, services for consumers.

The network approach is based on the synthesis of several economic theories: resource theory, evolutionary economic theory, management theory, knowledge economy, institutional theory, the doctrine of synergies, the economy of agreements and transactions. Hence, the logic of the network approach includes (Kelly, 2009) decentralization, synergy, community, free access, concern for network values, maximization of innovation, multidimensional space, lack of discontinuity, technology balance, expansion of the space of innovation opportunities.

Appropriate is the assertion by Paul Romer, Paul Krugman, and Kevin Kelley (Kelly, 1999): the values associated with the network function as stimulants the perception of the desired behaviour is the basis for creating the network and attracting the following 
participants; contribution to overcoming resistance to rapid changes and the spread of innovative behaviour.

The use of the network approach as a specific form of organization of innovative business chains began in the middle of the last century as a response to the challenges of scientific and technological progress, deepening the processes of globalization. At the same time, internationalization and integration of economic processes were observed. Enterprises of economically powerful countries began actively use various forms of integration, cooperation, and partnership. At the same time, the development of modern ICT has provided the formation of information and business communications between enterprises, significantly expanded the opportunities for their interaction. In fact, this form of organization of innovation activity helps enterprises to disseminate information about their innovative projects, supports at various stages of innovation, helps in finding business partners and clients.

That is, a hierarchical traditional structure, limited by national, legal, and bureaucratic borders, is replaced by a qualitatively new one, in which each enterprise has almost the same opportunities to attract resources and competences of other members of the network. The meaning of the network organization of innovation activity is concentrated in "the possibility for each of its participants to have equal direct relations with other participants" (Zvirko, 2012). Network interconnections of enterprises are determined by independence from spatial, time, resource constraints and are based on the capabilities of modern information and communication technologies, competitive advantages and competencies that apply to all enterprises included in it: risk minimization, high intensity of information flows, expansion of business combinations, coordination of innovation chains, multiplication of key competencies, optimal use of common assets.

"The network structure is a new model of redistribution of intellectual and production resources, it allows its subjects to minimize the time and material costs of adapting to market conditions." In conditions where the resources of high-tech enterprises are limited and do not meet the requirements of the competition, it is their network reorganization that allows redistributing the risks and reducing the time and financial costs for the development and implementation of innovations" (Moskovkin \& Rakovskaya-Samoylova \& Kovalenko, 2005).

\section{The experience of using a network approach in European countries}

The European Network of Business Innovation Centers (EBN) was established in the early 1980s on the initiative and at the expense of financing by the European Commission, it now carries out as a non-governmental non-profit association receiving funds from the EU only with participation in specialized projects on the competition on general grounds. Additional funding is provided for the provision of services to partners, contributions of network members and sponsorship. The network comprises almost 150 accredited members and up to 70 associates. Their permanent staffs consist of 13 people. The b-apartment is located in Brussels. An important function of the network is to manage the quality of business innovation centres: accreditation (by agreement with the EU) to obtain the status of a "European Business Innovation Centers" (EU-BIC). The EIC, the network of European innovation centres was established in 1987 by the European Commission. It united more than 300 organizations in 50 countries of the world, mainly its chambers of commerce, economic development agencies, banks and consulting companies, business associations (Castells, 2010).

\section{The experience of using a network approach in Ukraine}

At present, the development of network innovation structures in Ukraine can be considered fragmentary. There is an attempt to form or expand some network entities at the regional or national level (innovation centres, technology transfer centres, intellectual property commercialization departments, which unite partner and agent networks around them). Practically it is an attempt to introduce the experience of the EU countries on the domestic expenses, but their impact on the activation of innovative development for enterprises is not much appreciable. Note that there is a tendency to form formal network innovation structures. Mostly they perform functions of marketing networks by consulting agencies and the like. The reason for this is inadequate state support, low coverage of potential innovative enterprises, lack of development of intermediary innovative, investment, information structures, transfer and technology transfer centres, low qualification of personnel, lack of skills in the development of partner chains.

Summarizing the practical experience of using network innovation structures convinces that such a network forms a solid institutional basis for the innovative development of enterprises, creates the necessary information, organizational and economic prerequisites, and accumulates resources for successful innovation activity. It helps to coordinate the activities of enterprises, intermediaries, developers, scientists. Its role is to facilitate the continuous flow of new ideas, their development and commercialization, and the practical introduction of innovations in production. 


\section{Advantages and disadvantages of using a network approach to stimulate the innovation development for enterprises}

It is recognized that the formation of innovative networks has a relatively fast and significant positive effect, which gradually changes the very quality of innovative development of participating enterprises. The effectiveness of innovative networks is ensured by a low level of staff utilization and an optimal cost structure of resources. "Networks exclude the duplication of competent workforce and capacities in different sectors, thus avoiding high aggregate costs for the production of end products or for the intra-organizational exchange of services." The prerequisites for a network configuration without the use of surplus labour are in particular deep segmentation of all members of the network organization. In general, the network has a reserve potential, primarily due to the creation of new configurations or the attraction of additional partners (Popov, 1994).

At the same time, the innovative network is characterized by the following features: "the rejection of bureaucratization and formalization, the high status of information and personnel integration tools (combination of staff), the form of communication between the organization itself and other enterprises, for example, by creating internal markets, a small number of hierarchical levels thanks to the transition from a large centralized organization to a number of small organizations with flexible specialized forms of work" (Merriden, 2003).

Despite the conducted research, we are convinced that the implementation of the activation of innovative enterprise development based on the network approach reveals both new opportunities and has a number of limitations.

So the following additional possibilities are revealed: - increasing the adaptability of enterprises to changing environmental conditions;

- expansion of info-communication chains;

- reducing the level of risks and threats;

- the emergence of a rapid adequate response to changing consumer demand;

- multiplication of competence;

- adding competitive advantages;

- concentration and specialization of the company's activity on attractive unique processes;

- optimization of structure and volume of expenditures;

- avoiding the duplication of staff use;

providing creativity and flexibility;

- attracting the best specialists and partners;

- combination of interests of the enterprise with interests of the whole network.

At the same time, the innovation network generates a number of limitations that need to be considered when forming:
- lack of material support and social guarantees for its members due to the refusal of any long-term contracts; - focus on key competencies, narrow specialization, which does not provide for diversification of activities;

- excessive dependence on the professionalism of the staff;

- large risks due to staff turnover;

- great heterogeneity of participants and partners;

- danger of excessive complexity of the innovation process;

- dilution of participation and membership;

- high dynamics of changes within the network.

The formation of an innovative network for the activation of innovative development for enterprises in Ukraine is due to the following circumstances: the need to modernize the outdated material and technical base of many enterprises; growth in demand for high technology; wide dissemination and development of ICTs; availability of highly qualified specialists; the need for the technological renovation of the production; the insufficient level of the development of applied science, which hinders the introduction of innovations; the democratization of business models; the request for new values.

The purpose of creating an innovative network should be to increase the level of competitiveness of enterprises by enhancing their innovative development by expanding competencies, sharing resources, infrastructure, reducing the duration of innovation cycles; an increase of competitive advantages; risk reduction; an increase of innovation effectiveness.

\section{Proposals for the activation of enterprises' innovative development on the basis of a network approach}

The innovative network covers the areas of search, generation, and dissemination of ideas and the development and commercialization of innovations; it is a set of enterprises, organizations, objects of innovation infrastructure, public authorities that interact in the process of innovation and operate in the contour of a certain innovation policy.

An innovative network is formed by a number of subsystems: 1) education, vocational training and retraining of personnel (including universities, colleges, other institutions of secondary and vocational education, as well as the organization of retraining and professional development of personnel, taking into account the training and retraining of personnel for innovation); 2 ) subsystem of innovative activity, production and sales of products and services (including small, medium, and large enterprises, branch and regional innovation and technical centres, as well as concerns, corporations, and financial-industrial groups, trade (dealer) networks); 3) a subsystem of technological infrastructure (including centres for the support of innovative entrepreneurship, 
technology parks, telecommunications networks, business incubators and business innovation structures, consulting and engineering firms, information centres and technology transfer centres, a system of scientific and technical communications, together with a system of scientific and technical information, demonstration halls); 4) the financial infrastructure (contains organizational and legal mechanisms for financing and resource support for all stages of the innovation cycle with the investment companies, banks and other financial institutions, investment and innovation funds, venture funds, budget financing, if the customer is a state); 5) an information infrastructure subsystem (covering information resources, technologies and systems, information and telecommunications networks, ICT market)” (Shugurova, 2010).

Functions of the innovation network are: the promotion of innovative technologies; the search for innovative solutions for small and medium-sized technology-oriented enterprises, the reduction of operational, commercial, systemic, and criminal risks for them; the promotion of technological cooperation; the dissemination of data on research results among potential consumers, technological and organizational assistance expansion of access to these data for all participants of the innovation network, the systematization of technical information, organizations for partners of personnel and educational programs (Zgurovsky, 2006).

A key role in the development of network innovation structures belongs to the state authorities that establish rules of its functioning and provide legal, organizational, resource support. Such a support can be provided through the credit subsidization of innovation activities, the direction of investment funds in venture funds, preferential taxation, accelerated depreciation.

Thus, network innovation structures allow: improving the transfer of technologies by eliminating various obstacles in joint innovation activities; accelerating development of new technologies; coordinating innovation policy of all participants; generating additional competitive advantages; directing innovation activity in the context of consumer demand and market demands; activating the innovative development for small and medium-sized enterprises.

The implementation of advantages of a network approach in the area of activation of innovative development of enterprises is carried out when the following key prerequisites are fulfilled: restructuring the business chains of the participating enterprises themselves, forming network relations and business combinations of joint innovation activities and implementing certain norms of conduct and management regulations in the implementation of joint network projects; development of organizational infrastructure; existence of a high level of technological base development to ensure the effectiveness of communications between network participants.
To participate in an innovative network, each enterprise should make appropriate changes: to use new business models based on partnership and trust; to formulate new principles for managing business chains; to develop qualitatively new rules for mutual relations and innovative behaviour. At the same time, the key areas of innovative development of enterprises should be: outsourcing; reduction in the physical size of enterprises with a simultaneous increase in performance indicators; the transformation of technical and economic basis of production; expansion of business combinations; change of values and semantic content of innovative development of the enterprise.

Thus, it is possible to determine principles of enterprise network participation: "real-time work, which includes parallel work and organization; each employee should have an access to any information about the enterprise; support for the integrity of the enterprise through the creation of a network of teams; creation of a techno-organization conditions for the formation of "virtual" teams whose members may be located at different geographical points" (Wilkinson \& Young, 2002). The well-known rules for the successful individual behaviour of enterprises in networked entities are proposed by Kevin Kelly: "Everything is cheaper as it is perfected. It is worth to invent faster than the innovation becomes usual. It is not necessary to develop a product, but a network of business ties. New species constantly replace the old ones; the constant search for new possibilities, repetitions, copying, and automation depreciate, and originality and creativity grow in price" (Kelly, 2009).

\section{Conclusions}

The coverage of the role and problems of the innovative development for domestic enterprises, the disclosure of factors influencing these processes, the disclosure of the essence and substantiation of the expediency of using the network approach, the determination of its capabilities and limitations, the determination of the effectiveness of network innovation structures allowed to formulate proposals.

The use of such proposals for activating innovative development for enterprises in new dimensions of the economic space based on a network approach will help to stimulate the innovative development of domestic enterprises, effectively organize the rational interaction with partners, improve the quality of business chains, competitiveness of management structures, develop new market segments, improve the technology transfer by eliminating various obstacles in joint innovation, open up the new technologies, coordinate the innovation policy of all participants, generate the additional competitive advantages and competencies, align the innovation activities in the context of the consumer demand and the market demands. 


\section{References:}

Zvirko, M.V. (2012). Setevaya ekonomika: ponyatie, preimuschestva i nedostatki [Network economy: concept, advantages and disadvantages]. Teoriya i praktika obschestvennogo razvitiya - Theory and practice of social development, №1. Retrieved from http://www.teoria-practica.ru/rus/files/arhiv_zhurnala/2012/1/ekonomika /zvirko.pdf (in Russian).

Zgurovsky, M.Z. (2006). Bolonskyy protses: holovni pryntsypy ta shlyakhy strukturnoho reformuvannya vyshchoyi osvity Ukrayiny [Bologna Process: Main Principles and Ways of Structural Reform of Higher Education of Ukraine]. Kiev: National Technical University of Ukraine "Kyiv Polytechnic Institute" (in Ukraine).

Ivchenko, V. (2007). Stanovlennia ta rozvytok natsionalnoi innovatsiinoi systemy Ukrainy yak peredumovy pobudovy konkurentnospromozhnoi ekonomiky derzhavy [Formation and development of the national innovation system of Ukraine as a prerequisite for building a competitive state economy]. Stratehiia rozvytku Ukrainy - Strategy of development of Ukraine, № 1/2, 246-252 (in Ukraine).

Castells, M. (2010). Information Age: Economics, Society, Culture. 2nd ed. Oxford: Wiley Blackwell.

Merriden, T. (2003). Biznes put: Nokia. Sekrety uspekha samoj bystrorazvivayushchejsya kompanii v mire [Business Way: Nokia. Secrets to the success of the fastest growing company in the world]. St. Petersburg: Publishing house "Krylov" (in Russian).

Moskovkin, V.M., \& Rakovskaya-Samoylova A.H., \& Kovalenko V.N. (2005). Tematicheskie seti innovacionnyh regionov Evropy: opyt dlya postsovetskih evropejskih stran [Thematic Networks of Innovative Regions of Europe: Experiences for Post-Soviet European]. Vestnik Mezhdunarodnogo Slavyanskogo universiteta. Ser. Ekonomicheskie nauki - Bulletin of the International Slavic University. Ser. Economic sciences, Vol. 8, № 1-2, 3-11 (in Russian).

Site of the World Intellectual Property Organization. Retrieved from http://www.wipo.int/portal/en/index.html Ofitsiinyi sait Derzhavnoyi sluzhby statystyky [Site of the State Statistics Service of Ukraine] Retrieved from http:/ / www.ukrstat.gov.ua (in Ukraine).

Popov, V.N. (1994). Organizacionno ehkonomicheskij mekhanizm obedineniya: (na primere nauchno-proizvodstvennogo koncerna) [Organizational-economic mechanism of association (on an example of a scientific-production concern)]. Voronezh: Publishing House of the VSU (in Russian).

Sichkarenko, K.O. (2015). Merezheva orhanizatsiya innovatsiynoyi diyalnosti : naukova dopovid [Networking organization of innovation activity : scientific report]. Kiev: National Academy of Sciences of Ukraine, Institute of Economics and Forecasting, National Academy of Sciences of Ukraine (in Ukraine).

Shugurova, I.V. (2010). Politiko-pravovye aspekty transfera rossijskih tekhnologij za rubezh [Political and legal aspects of transfer of Russian technologies abroad]. Mezhdunarodnye processy - International processes, № $1,78-81$ (in Russian).

Global Innovation Index 2016. World Intellectual Property Organization. Retrieved from http://www.wipo.int/ edocs/pubdocs/en/wipo_pub_gii_2016.pdf

Communication from the Commission. Europe 2020. A strategy for smart, sustainable and inclusive growth. European Commission. Retrieved from http://ec.europa.eu/europe2020/pdf/themes/15_research_development.pdf

Innovation Union Scoreboard (2016). European Commission. Retrieved from http://ec.europa.eu/growth/ industry/innovation/facts-figures/ scoreboards /files/ius - 2016_e n.pdf

Kelly, K. (2009). Health Science Libraries: future trends. An Leabharlann. The Irish Library, № 18(1), 12-17. Retrieved from http://epubs.rcsi.ie/libraryart/4/

Kelly, K. (1999) Nowe reguty nowej gospodarki. Dziesięć przełomowych strategii dla świata połaczonego siecia [New Rules for the New Economy. 10 Radical Strategies for a Connected World]. London: Penguin.

The Bloomberg Innovation Index (2017). Bloomberg. Retrieved from http://www.bloomberg.com/graphics/2017innovative-countries/

Wilkinson, I., \& Young L. (2002). On Cooperating: Firms, Relations and Networks. Sydney University of Technology Journal of Business Research. Retrieved from http://necsi.edu/events/iccs6/viewpaper.php?id=128 